Rozprawy Komisji Językowej ŁTN, t. LXVII, 2019

ISSN 0076-0390; e-ISSN 2450-9310

https://doi.org/10.26485/RKJ/2019/67/13

\title{
Zofia Kubiszyn-Mędrala*
}

(D) https://orcid.org/0000-0003-4465-1916

\section{ANTROPONIMY W UTWORACH KRESOWYCH WLODZIMIERZA ODOJEWSKIEGO I ICH FUNKCJE ARTYSTYCZNE}

\author{
ANTHROPONYMS IN THE KRESY WORKS \\ BY WŁODZIMIERZ ODOJEWSKI AND THEIR ARTISTIC FUNCTION
}

The subject of this article are names and surnames of literary figures in three works by Włodzimierz Odojewski, constituting the so called "Kresy cycle". The author presents the origin and etymology of examined names as well as their artistic functions.

Keywords: onomastics, literary anthroponyms, functions of personal names in literature

Słowa kluczowe: onomastyka, antroponimy literackie, funkcje nazw osobowych w literaturze

\section{WPROWADZENIE}

Funkcjom artystycznym nazw własnych w literaturze pięknej poświęcono już wiele uwagi. Bogaty materiał na ten temat zebrały w bibliografii polskiej onomastyki literackiej Irena Sarnowska-Giefing i Magdalena Korzeniewska-Gosieniecka [2001] oraz Irena Sarnowska-Giefing, Magdalena Graf i Joanna Grzelak-Piastowska [2013]. Należy tu wspomnieć, że nazwy własne w literaturze pięknej są wtórne wobec onimii uzualnej, pozaliterackiej i w konkretnym utworze ich rodzaj, a także pełnione przez nie funkcje uzależnione są od tematyki dzieła, rodzaju fikcji literackiej, gatunku czy nurtu [Cieślikowa, 2001, s. 101].

Celem niniejszego artykułu jest przedstawienie antroponimów (nazwisk i imion), które tworzą onomastyczny paradygmat w trylogii ukraińskiej

* Uniwersytet Jagielloński, Wydział Polonistyki, Katedra Lingwistyki Kulturowej i Socjolingwistyki, 30-001 Kraków, ul. Gołębia 20; e-mail: zofia.kubiszyn-medrala@uj.edu.pl. 
Odojewskiego, a także omówienie ich genezy i funkcji artystycznych, które pełnią w wymienionych niżej utworach.

Włodzimierz Odojewski (1930-2016) to wybitny reprezentant nurtu kresowego polskiej prozy po roku 1945. Przez badaczy zaliczany jest do tzw. szkoły ukraińskiej [Stabro, 2002, s. 64]. W jego twórczości ${ }^{1}$ wyróżniają się utwory określane jako cykl kresowy lub cykl ukraiński albo też podolski². Charakteryzują się one jednolitością problematyki, oryginalnym kształtem artystycznym, utożsamianym z idiolektem pisarza, który określono terminem odojewszczyzna [Bieńkowski, 1999]. Na ów cykl składają się następujące utwory: zbiór opowiadań pt. Zmierzch świata, kilka powieści: Wyspa ocalenia, Zasypie wszystko, zawieje..., a także fragmenty nieukończonej powieści pt. Odejść, zapomnieć, $\dot{z y c ́} . . .$, publikowane na łamach czasopism emigracyjnych. W niniejszym artykule analizą zostały objęte utwory: Wyspa ocalenia [dalej WO], Zmierzch świata [ZŚ] oraz Zasypie wszystko, zawieje... [ZWZ].

Fabuła cyklu obejmuje fragmentarycznie odtworzone wydarzenia, które rozegrały się wśród mieszkańców Wołynia i Podola (na dawnych Kresach), dotkniętych sowiecką inwazją, niemiecką okupacją w 1939 roku, zbrodnią katyńską i bratobójczą walką z Ukraińcami w latach 1943-1944. Przedstawiony w trylogii mroczny obraz Ukrainy lat czterdziestych obejmuje krwawe rzezie dokonywane na ludności żydowskiej i polskiej przez Niemców, pacyfikacje wsi i dworów, wzajemne mordowanie się Polaków i Ukraińców, walki polskich, ukraińskich i sowieckich partyzantów.

Bohaterami cyklu uczynił Odojewski dwa spokrewnione ze sobą rody - polską rodzinę szlachecką Woynowiczów oraz spolszczonych arystokratów Czerestwienskich, którzy znaleźli schronienie na Ukrainie po rewolucji w Rosji w 1917 roku. Przez pryzmat skomplikowanych związków uczuciowych Pawła Woynowicza z jego bratową Katarzyna, wdową po zamordowanym w Katyniu Aleksym, a także Piotra Czerestwienskiego z Katarzyna, Odojewski ukazał schyłek polskiej kultury szlacheckiej na Kresach. Natomiast wątek Semena Gawryluka, nieślubnego syna księcia Czerestwienskiego i przyrodniego brata Piotra, posłużył autorowi do odtworzenia najbardziej dramatycznego okresu w konfliktach narodowościowych na Ukrainie.

1 Różnorodna twórczość Odojewskiego obejmuje między innymi utwory poetyckie i dramaturgiczne, scenariusze słuchowisk radiowych i widowisk telewizyjnych, powieści i opowiadania o tematyce współczesnej oraz powieści historyczno-przygodowe, prace krytycznoliterackie i publicystyczne.

2 Zob. Inga Iwasiów [1994], Ewa Szczepkowska [2002], Magdalena Rembowska-Płóciennik [2004], Grzegorz Czerwiński [2011] oraz Stanisław Barć [1999] i tam podana bibliografia. 
Pisarz przedstawia rzeczywistość Kresów podolskich przez psychikę swoich bohaterów, w której realizm miesza się z mitotwórstwem, teraźniejszość z przeszłością, a wspomnienia odległych w czasie i przestrzeni wydarzeń, miejsc i postaci nakładają się na siebie. Do ukazania świata przedstawionego z punktu widzenia Piotra Czerestwienskiego i Pawła Woynowicza autor posłużył się techniką pisarską zwaną strumieniem świadomości, która determinuje rzeczywistość Kresów podolskich, istniejąca już tylko w pamięci bohaterów. Technika ta przekłada się przede wszystkim na wyznaczanie warstwy proprialnej analizowanych tutaj utworów.

Przedstawiony przez Odojewskiego w utworach świat Kresów obejmuje społeczeństwo zróżnicowane etnicznie, składające się z Polaków, Ukraińców, Rosjan, Żydów, stacjonujących tam Niemców i Węgrów. W tej etnicznie różnorodnej grupie postaci pisarz wyodrębnia i nazywa około 150 osób. Większość z nich pojawia się tylko raz czy dwa, inne tworzą tło historyczne. Literacki antroponomastykon trylogii ukraińskiej tworzą nazwy osobowe autentyczne leksykalnie i denotacyjnie oraz nazwy autentyczne leksykalnie, ale nazywające postaci fikcyjne, a także nieliczne nazwy nieautentyczne, utworzone przez autora.

W utworach Odojewskiego antroponimy pełnią następujące funkcje: lokalizacyjną w czasie i przestrzeni, informacyjna, identyfikacyjno-dyferencjacyjna, socjologiczną, semantyczną (treściową), intertekstualną oraz mitotwórczą, przy czym w jednym onimie może łączyć się równocześnie kilka funkcji.

\section{FUNKCJA LOKALIZACYJNA I INFORMACYJNA}

Funkcję lokalizacji w czasie pełnią w literaturze antroponimy autentyczne leksykalnie, denotujące osoby rzeczywiste, które - zdaniem Czesława Kosyla [1992, s. 62] - wprowadzone do utworu literackiego odgrywają rolę wyrazów-świadków epoki. Nazwy przeniesione z nazewnictwa realnego do utworów literackich, oznaczające ten sam denotat co w rzeczywistości pozaliterackiej mogą odnosić się do określonych wydarzeń historycznych i politycznych, pełniąc równocześnie funkcję lokalizacji w czasie i informacyjną [Kosyl, 1992, s. 62]. W badanym materiale nazwy występujące w tej podwójnej funkcji nie stanowią jednak licznej grupy. Na umiejscowienie fabuły w określonym czasie (przy braku innych wyznaczników temporalnych) wskazują między innymi nazwiska:

1) przywódców państwowych, jak: Stalin, Churchill: „Przecież pan wie, majorze, że po wywleczeniu na światło sprawy katyńskiej Stalin zerwał stosunki dyplomatyczne z naszym rządem... Mało mnie to obchodzi. On dalej na angielskiej i amerykańskiej pomocy jedzie czy nie? Churchill w zamian takiego drobiazgu nie potrafi na Stalinie wymóc?" [ZWZ, s. 52]; 
2) generałów wojskowych, jak: generat Sikorski: „Wuj August mówił o kolejnych doniesieniach niemieckich gazet na temat śmierci generała Sikorskiego" [ZWZ, s. 139].

Nazwiska te, umiejscowione w określonym kontekście historycznym, ewokują wydarzenia z wiosny (podanie przez Niemców informacji dotyczącej odkrycia grobów polskich w Katyniu) i lata (katastrofa lotnicza na Gibraltarze) 1943 roku. W reminiscencjach bohatera dotyczących walk z bolszewikami w 1920 roku lokalizację czasową wywołuje nazwisko Piłsudskiego: ,[...] ojciec bił się o tę ziemię w legionach Piłsudskiego [...]” [ZWZ, s. 223], a także Budionnego ${ }^{3}$ : ,[...] to właśnie pokolenie Kaniowskiego wpływało decydująco na losy kraju w roku dwudziestym, gdy trzeba było odpierać watahy Budionnego" [ZWZ, s. 601].

Osadzeniu akcji w czasie i przestrzeni służą natomiast nazwiska radzieckich generałów i ukraińskich przywódców nacjonalistycznych, jak: generał Begma ${ }^{4}$ : „Mówią o czerwonych generała Begmy, proszu ja pana, że zza Zbrucza coraz ich więcej sia ku nam pcha" [ZWZ, s. 152], Własow ${ }^{5}$ : „traktem zaś przewalały się oddziały Własowa” [ZŚ, s. 138], Bandera ${ }^{6}$, ,nacjonaliści ukraińscy spod znaku Bandery” [ZWZ, s. 519], Taras Bulba7: „Taras Bulba, czy co?” [ZWZ, s. 153], Melnyk: ,„poznał Ukraińców pewnie tych spod znaku Melnyka” [ZWZ, s. 309].

Na lokalizację przestrzenną świata przedstawionego wskazuje ponadto nazwa rodu arystokratycznego zamieszkującego tereny Ukrainy - Sas-Terleckich: ,Jeździliśmy do panów Sas-Terleckich. Jeszcze z naszymi ojcami” [ZWZ, s. 153]. Według historyków, Terleccy herbu Sas zamieszkiwali w województwie ruskim od 1532 roku [Leszczyc, 1990, s. 293, za: Krzyżanowski, 1999, s. 320].

3 Siemion Budionny (1883-1973) - rosyjski i radziecki dowódca wojskowy. W czasie wojny polsko-bolszewickiej 1920 roku dowodził 1 . Armią Konną walczącą z wojskiem polskim na Ukrainie.

4 Wasilij Begma (1906-1965) - radziecki działacz partyjny, generał major Armii Czerwonej. W latach 1943-1944 dowodził radzieckimi oddziałami partyzanckimi na Wołyniu.

5 Andriej Własow (1901-1946) - generał Armii Czerwonej, dowódca Rosyjskiej Armii Wyzwoleńczej (ROA), oddziałów białogwardyjskich współpracujących w latach II wojny światowej z Niemcami.

${ }^{6}$ Stepan Bandera (1908-1959) - przywódca Organizacji Ukraińskich Nacjonalistów (UON), banderowców.

7 Taras Boroweć, pseud. Bulba (1908-1981) - ukraiński działacz polityczny, przywódca jednego z nacjonalistycznych ugrupowań ukraińskich - Siczy Poleskiej UPA.

8 Andrij Melnyk (1890-1964) - przywódca frakcji Organizacji Ukraińskich Nacjonalistów (UON), melnykowców. 


\section{FUNKCJA IDENTYFIKACYJNO-DYFERENCJACYJNA}

Funkcja identyfikacyjno-dyferencjacyjna ma charakter uniwersalny dla nomen proprium. W utworach literackich polega na wyodrębnieniu i zróżnicowaniu postaci za pomocą odpowiednich typów nazw osobowych [Kosyl, 1992, s. 50]. W badanych utworach formuły denotujące i identyfikujące bohaterów fikcyjnych, uwzględniające co prawda punkt widzenia narratora w jego opowieści, odwołują się do sposobów nazywania osób w rzeczywistości pozaliterackiej. Formuły te nie tylko identyfikują postaci, ale także w wielu przypadkach określają ich pochodzenie narodowe czy społeczne (funkcja identyfikacyjno-dyferencjacyjna zespala się tutaj z funkcją socjologiczną nazw własnych).

Pochodząca ze wschodniosłowiańskiego systemu antroponimicznego trójelementowa formuła identyfikacyjna, składająca się z imienia, otczestwa i nazwiska, w cyklu powieściowym występuje tylko w odniesieniu do jednej postaci: Mikołaja Fiodorowicza Czerestwienskiego - seniora rodu, rosyjskiego emigranta, Białego Rosjanina. Jego narodowe pochodzenie podkreśla inna formuła identyfikacyjna, odwołująca się do nacechowanego chronologicznie etnonimu: stary Moskal z Czupryni [ZWZ, s. 54].

Dwuelementowym określeniem antroponimicznym, składającym się z imienia i nazwiska, identyfikowani są główni bohaterowie: Paweł Woynowicz, Piotr Czerestwienski, Teodor Czerestwienski, Semen Gawryluk. Podobnie, ale sporadycznie identyfikowani są bohaterowie drugoplanowi lub nawet epizodyczni, np.: Arkadiusz Mamont: „,nazywał się Mamont, Arkadiusz Mamont” [ZWZ, s. 86] czy pastuch Iwan Hryta [ZWZ, s. 494]. Nieliczne postaci drugoplanowe przyjmują obok nazwiska derywowane imię hipokorystyczne, np.: Fiedka Czerkwas [ZŚ, s. 120], Wasylko Hanczar [ZWZ, s. 336], Niko Fiodorczuk [ZWZ, s. 381].

Samym imieniem denotowani i identyfikowani są członkowie rodziny, np. wuj August, stryj Teodor, pradziadek Stefan, stryjenka Matgorzata, ciotka Felicja itd., oraz służba dworska, np. pokojówka Róża, kucharka Prakseda, piastunka Paraska.

Perspektywa narracyjna strumienia świadomości bohaterów motywuje używanie samego imienia, zawsze w pełnej, metrykalnej postaci w odniesieniu do Katarzyny, wdowy po Aleksym, której postać, a także nazwanie ma w analizowanym cyklu swoistą rolę [Krzyżanowski, 1999, s. 327-328].

Postaci drugoplanowe najczęściej denotowane i wyodrębniane są nazwiskiem poprzedzonym dodatkowym określeniem wskazującym na zajmowaną pozycję społeczną, zawód lub rodzaj wykonywanego zajęcia np.: dziedzic Kaniowski [ZWZ, s. 554], mecenas Lipski [ZWZ, s. 156], ksiadz proboszcz Lipiec [ZWZ, s. 396], pop Martynienka [ZWZ, s. 337], poddiaczy Wasow [ZWZ, s. 541], oraz: 
fornal Buczany [ZWZ, s. 487], stajenny Chrobak [ZWZ, s. 104], skotarz Czuwaj [ZWZ, s. 348], stangret Feduszycki [ZWZ, s. 425], stelmach Hanczar [ZWZ, s. 146], ślusarz Imach [ZWZ, s. 398], gorzelany Karpatka [ZWZ, s. 154], furman Skotnicki [ZWZ, s. 498], karczmarz Sobiszczuk [ZWZ, s. 44], masztalerz Zbroż [ZWZ, s. 476], ekonom Waśkowski [ZWZ, s. 148].

Liczni partyzanci identyfikowani są nazwiskiem z nazwą stopnia wojskowego, np.: podputkownik Laudański [ZWZ, s. 49], major Draża [ZWZ, s. 52], porucznik Hultas [ZWZ, s. 290], porucznik Maciaczyk [ZŚ, s. 295], porucznik Tałtach [ZWZ, s. 452], wachmistrz Szyła [ZWZ, s. 320], a także tylko nazwiskiem, np.: Natańczyk [ZŚ, s. 242], Zachwiej [ZWZ, s. 398], Tatarczuk [ZWZ, s. 398], Tuchocki [ZWZ, s. 320], Tyszka [ZWZ, s. 398] i inni.

$\mathrm{W}$ trylogii Odojewskiego rzadko pojawiają się pseudonimy partyzanckie, np. wachmistrz Kuprian [ZWZ, s. 424], którego motywację objaśnia narrator: „Kuprian to było przecież tylko imię, teraz widać używane jako partyzancki pseudonim. Kuprian Szyła” [ZWZ, s. 426] czy Stoń: „Porucznik Gugla, ten wiesz, pseudonim Słoń" [ZWZ, s. 161].

Postaci marginalne, wzmiankowane tylko, denotowane i wyodrębniane są nielicznymi formami odimiennymi utworzonymi sufiksem -ko, np.: szpicel wiejski, Antyp-ko [ZWZ, s. 124], dziad cerkiewny Filip-ko [ZWZ, s. 342], pastuch Nikit-ko [ZWZ, s. 343]. Formant ten spotykany jest w antroponimii ukraińskiej [zob. Wolnicz-Pawłowska, Szulowska, 1998, s. 96-97].

Uwagę przyciągają formacje identyfikujące, wywodzące się z potocznego systemu nazywania osób, które zawierają odniesienia pokoleniowe poświadczone w konstrukcjach z epitetem stary, senior lub młody, np.: stara pani Czerestwienska, babka Piotra [ZWZ, s. 16], stary Poczochraj [ZWZ, s. 372], wspomniany wyżej stary Moskal, senior Czrestwienski, Mikołaj Fiodorowicz [ZWZ, s. 13], młody pan Czerestwienski [ZŚ, s. 89], młody Kaniowski [ZWZ, s. 156], a także zestawienia wskazujące na zależności rodzinne w nazwaniach synów, np.: Czartoriusowy najstarszy [ZWZ, s. 364], najstarszy syn Pankali, Jur [ZWZ, s. 367], syn stelmacha Hanczara, Józwa [ZŚ, s. 89], syn najmitki Sewrukowej, Iwan [ZWZ, s. 477], poddiaczych Wasowów syn - Nikodem [ZWZ, s. 477], Kuźma Brent, nieślubny Brenciny [ZWZ, s. 477] i córek, np.: Antypkowa Zojka [ZWZ, s. 373], córka popa Łarysa [ZWZ, s. 343], popadianka Larysa [ZWZ, s. 345].

Odnotować tutaj należy także formacje marytonimiczne, denotujące i wyróżniające kobiety zamężne, utworzone od nazwisk mężów sufiksem -owa: Czartoriusowa, Czeptunowa, Derczekowa, Karpatkowa, Petrysowa, Sewrukowa, Woynowiczowa, a w jednym tylko przypadku sufiksem -ina: Brencina $(<\operatorname{Brent}(a))$. 
Powyższe zestawienia, zawierające odniesienia do relacji pokoleniowych i rodzinnych, poza identyfikacją i dyferencjacją postaci niosą również informacje socjologiczne.

\section{FUNKCJA SOCJOLOGICZNA}

Antroponimy występujące w cyklu podolskim nie tylko identyfikują postaci literackie - biorą one także istotny udział w charakterystyce narodowościowej i środowiskowej bohaterów.

Nośnikiem funkcji socjologicznej, wskazującym na pochodzenie regionalne i społeczne bohaterów, jest nazwisko rodu Woynowiczów [autentyczne leksykalnie, NP II, s. 695] - polskiej rodziny ziemiańskiej, mieszkającej od pokoleń na Kresach ${ }^{9}$. O wielowiekowej tradycji rodu może świadczyć pisownia nazwiska Woynowicz, w której głoska $j$ zapisywana jest przez $y$. Natomiast na kresowe pochodzenie może wskazywać wschodniosłowiański patronimiczny z genezy sufiks -owicz. Nazwiska z takim formantem były charakterystyczne dla warstwy szlacheckiej [Wolnicz-Pawłowska, Szulowska, 1998, s. 183-187]. Elementem kresowym jest także imię Aleksy, utworzone od pełnego imienia Aleksander, być może pod wpływem samodzielnego imienia Aleksy, używanego zwłaszcza na Kresach Południowych [zob. SEM, cz. 2, s. 7]. Pełna, metrykalna postać imienia w całym cyklu powieściowym pojawia się sporadycznie, na przykład w wykazie oficerów wydobytych z mogił katyńskich: „Porucznik Aleksander Woynowicz” [ZWZ, s. 128].

Przynależność do rosyjskiego rodu Czerestwienskich widoczna jest w użytym zestawieniu identyfikującym seniora rodu, to znaczy zawierającym imię i otczestwo oraz nazwisko: Mikołaj Fiodorowicz Czerestwienski. Wyraźnym sygnałem jego wschodniosłowiańskiej proweniencji jest tu pełnogłos. Nazwisko to nie jest autentyczne ${ }^{10}$. Prawdopodobnie utworzono je na wzór rosyjskiego autentycznego nazwiska typu Rożdiestwienskij ${ }^{11}$. Zamiast Rożdies- wstawiono rosyjski przyimek czerez 'przez'. Powstałe w ten sposób nazwisko pełni nie tylko funkcję socjologiczna, określając przynależność narodową, ale i niesie dodatkowe treści (zob. funkcja semantyczna nazwy własnej), charakteryzując pośrednio postaci tym onimem nazwane. Określa ludzi, którzy przeszli przez pewną granicę (najstarszy

${ }^{9} \mathrm{O}$ związkach rodu Woynowiczów z ziemią kresową por. fragment monologu ,,[...] on, Paweł Woynowicz - którego zrodziła ta ziemia, jak zrodziła jego dziadów i pradziadów, jak daleko tylko sięgnąć w pomrokę jej dziejów, bo zawsze byli na tej ziemi, znikąd nie przyszli [...] [ZWZ, s. 10].

${ }^{10}$ Odwołuję się tutaj do wywodu Jerzego Krzyżanowskiego [1999, s. 325].

${ }^{11}$ Nazwisko Rożdiestwienskij nosił między innymi Zinowij (1848-1909), admirał rosyjski. 
przedstawiciel rodu Mikołaj Fiodorowicz uciekł przez granicę z objętej rewolucją Rosji i osiadł w Polsce), ale znajdują się wciąż w stanie przejściowym ${ }^{12}$.

To symboliczne zawieszenie między krajem swojego pochodzenia a krajem obecnego pobytu uwidacznia forma fonetyczna i strukturalna nazwiska: Czerestwienski $\mathrm{w}$ całym cyklu pisane jest zawsze przez twarde $n$ nigdy przez $\dot{n}-$ jak w języku polskim, ale z polskim sufiksem -ski zamiast rosyjskiego -skij. Owa wschodniosłowiańska postać sufiksu -skij pojawia się tylko w wypowiedzi ukraińskiego nieślubnego syna jednego z książąt Czerestwienskich - Semena Gawryluka: „Uże ne ty Czereswienskij, my Czerestwienskije” [ZWZ, s. 525], co niesie głębsze treści w wymiarze ideowym utworu.

Odojewski, kreując w swoich utworach świat Kresów i ludzi je zamieszkujących, odwołuje się do najbardziej typowych określeń antroponimicznych, właściwych dla tego regionu. Można powiedzieć, że operuje stereotypami antroponimicznymi. Do nazwania ludności ukraińskiej wykorzystuje autentyczne nazwiska i imiona wywodzące się z antroponimii ukraińskiej. Najczęstszymi nazwiskami, charakterystycznymi dla nazewnictwa chłopskiego, są formacje zakończone patronimicznym sufiksem -czuk lub -uk [Wolnicz-Pawłowska, Szulowska, 1998, s. 191]. Zazwyczaj dołączano je do podstaw apelatywnych, np.: Bondar-czuk ( $<$ n. os. Bondar < ukr. bondar 'bednarz') lub Bondarcz-uk $(<$ n. os. Bondarek) [NP I, s. 26], Slip-czuk (< n. os. Slip < ukr. slipij 'ślepy') lub Slipcz-uk (n. os. Slipko) [NP II, s. 578], etnonimów, np.: Tatar-czuk $(<$ n. os. Tatar) lub Tatarcz-uk (<n. os. Tatarek) [NP II, s. 598], częściej od imion, np.: Iwani-uk (< Iwan) [NP I, s. 334], Prokopi-uk (< Prokop) [NP II, s. 299], Sewr-uk $(<$ Sewer) [NP II, s. 411], Sobisz-czuk $(<$ Sobiesz $<$ Sobiestaw) [NP II, s. 404] lub Sobiszcz-uk (< Sobieszko) [SEM, cz. 1, s. 281], Tom-czuk $(<$ Tom) lub Tomcz-uk $(<$ Tomko) [NP II, s. 610-611] i inne.

Nazwisko Gawryluk (< Gawryl < Hawryto używane na Kresach Wschodnich) [NP I, s. 209] nosi „najbardziej krwawy ataman na Podolu od Beskidu po Wołyń” [ZWZ, s. 106], nieślubny syn księcia Czerestwienskiego i ukraińskiej dziewczyny.

${ }^{12}$ Znamienny pod tym względem jest następujący fragment dotyczący Piotra Czerestwienskiego: „W każdym razie Piotr poczuł wówczas, jak to wszystko, o czym marzył: spokój, stabilizacja, pewność, to, do czego dążył, jadąc do dziadków na Kresy, a także to, z czym wiązało się jego wyobrażenie własnej przyszłości: dom, majątek, stanowisko, miejsce w społeczeństwie (w które on, pół Rosjanin, pół Polak wrośnie, a ono go przyjmie, tak, że nie zazna już nigdy, jak jego ojciec, owego przerażającego ich, Czerestwienskich, poczucia obcości), rodzina, przyszła rodzina własna może też, przede wszystkim zaś tradycja, duma rodowa, świadomość trwania w historii, w ogóle trwanie - wszystko to rozpada się w gruzy, rozwiewa bezszelestnie w powietrzu, jak dym z palonych przez jego brata wsi okolicznych, tonie w krwi toczonej przez tamtego, nie zostawiając po sobie nic, czego można by się jeszcze uczepić" [ZWZ, s. 516]. 
Nazwiska z powyższymi sufiksami użyte $\mathrm{w}$ formie pluralnej stają się metaforą ukraińskości i bratobójczych walk: „Za bratnią krew, co ją co pokolenie musimy tu na Kresach upuszczać. Tych wszystkich Poczajewów, Iwaniuków, Gawryluków... Żeby oni nam jej nie upuścili. Albo dlatego, że jej upuścili” [ZWZ, s. 172].

Sufiks -czuk dołączony do wschodniosłowiańskiego imienia Fiodor tworzy nazwisko Fiodorczuk [NP II, s. 603], denotujące służącego przybyłego na Kresy z Rosji wraz z Czerestwienskimi („Czerkwasowie i Fiodorczukowie byli tak samo jak dziadek Piotra Rosjanami, razem z nim poszli na emigrację, osiedli w Polsce" [WO, s. 55]).

W nazwaniach ludności pochodzenia ukraińskiego pisarz wykorzystuje nazwiska formalnie równe imionom cerkiewnym ${ }^{13}$, np.: Mykieta $(<\mathrm{im}$. cerk. Mikita, Nikita) [NP II, s. 96] Hawryta (< Hawryta) [NP I, s. 210], oraz derywaty utworzone od tych imion, np.: Hryła (< Hrihoryj), Hryćko $(<$ Hryć $<$ Hryhory) [NP I, 276] i inne.

Nazwiska pochodzące od imion cerkiewnych noszą nie tylko bohaterowie ukraińscy, ale także przedstawiciele innych nacji wschodniosłowiańskich, na przykład kapitan armii carskiej Mamont (< im. Mamant, Mamont) [NP II, s. 63] czy partyzant radziecki Maksimow (< im. Maksim) [NP II, s. 58]: ,partyzantka sowiecka niejakiego Maksimowa" [ZWZ, s. 405].

Wśród imion określających ludność pochodzenia ukraińskiego wymienić należy: imiona żeńskie: Agrypina (cerk. Agrippina), Larysa, Prakseda, Paraska (cerk. Paraskiewa), a także męskie: Danitła (cerk. Danitl), Iwan, Jur (cerk. Jurij), Kuprian (Cyprian, cerk. Kiprian), Kuźma (cerk. Kosma), Nikodem, Ostap (cerk. Jewstafij), Semen (Symeon, cerk. Simieon), Wasilij/Wasyl oraz derywaty odimienne z sufiksem -ko, np.: Antypko (< cerk. Antip), Filipko (<Filip), Nikitko $(<$ Nikita), Wasylko $(<$ Wasyl).

W nazywaniu bohaterów literackich będących przedstawicielami polskich środowisk szlacheckich oraz chłopskich Odojewski wykorzystuje nazwiska autentyczne - odmiejscowe, zakończone sufiksami -ski, -cki. Noszą je właściciele ziemscy, np.: Humięcki $(<\mathrm{n}$. m. Humięcino) [NP I, s. 315], Kaniowski $(<\mathrm{n} . \mathrm{m}$. Kaniewo) [NP I, s. 374], Lipski (< n. m. Lipa, Lipie) [NP II, s. 22], Skotnicki $(<\mathrm{n}$. m. Skotniki) [NP II, s. 436], Waśkowski (<n. m. Waśki) [NP II, s. 658] i inni.

W kreacjach onimicznych postaci narodowości polskiej autor wykorzystuje różnorodne formy nazwiskowe zaczerpnięte $\mathrm{z}$ autentycznej antroponimii - odimienne, np.: Natań-czyk (< Natan) [NP I, s. 140], Tom-ecki (< Tomasz) [NP II,

${ }^{13}$ Wszystkie imiona cerkiewne w postaci pełnej oraz ich derywaty odnotowuje Bazyli Tichoniuk [2000] oraz SIP. 
s. 610], Zbroż (< Ambroży) [NP I, s. 4] i odapelatywne, np.: Dolata (< ap. dolatać) [NP I, s. 140], Lipiec (< ap. lipiec) [NP II, s. 22], Tuch-ocki $(<$ psł. *tucha 'odwaga') [NP II, s. 626], Zachwiej (< ap. zachwieja 'zawieja') [NP II, s. 729], Żar-ko (< ap. żar) [NP II, s. 757] i inne.

Maria Karpluk tak pisze o zapamiętanych nazwiskach kresowych: „Nierozerwalny, utrwalony wiekami splot społeczny, widoczny jest [...] w nazwiskach" [Karpluk, 2009, s. 85]. Na kartach trylogii podolskiej Odojewskiego splot ten widoczny jest w zestawieniu wschodniosłowiańskiego imienia Daniłla z nazwiskiem Stefański, zakończonym na -ski [ZWZ, s. 633; NP II, s. 481], a także w połączeniu nazwiska na -owicz ze słowiańskim imieniem syna, ale ze wschodniosłowiańskim imieniem ojca: „Ja, Kondratowicz Jarosław, pana Wasilija z Kondratowej syn” [ZWZ, s. 504; NP I, s. 434].

Nieliczni nazwani z imienia i nazwiska Żydzi noszą miana właściwe dla tej grupy narodowej, np. imiona Izaak, Jowka (< im. bibl. Jow, Job, Hiob) [zob. SEŻ, s. 157], Smul (< Samuel - IŻ, s. 119 notuje formę Szmul) i nazwiska, przeważnie złożone, oparte na niemieckich rdzeniach, np.: Arnsztejn (<arn-<im. Arnold, bibl. Aron lub < ap. niem. arm 'biedny, ubogi' + ap. niem. Stein 'kamien') [SEŻ, s. 55, 299], Baumriter (< ap. niem. Baum 'drzewo' + riter 'żołnierz, wojownik, jeździec') [SEŻ, s. 62, SEM, cz. 5, s. 209], Rosen (< ap. niem. Rose 'róża') [SEŻ, s. 283].

Kilka postaci pochodzenia niemieckiego nosi autentyczne leksykalnie nazwiska niemieckie np.: Berger [DUD, s. 107], Hese [DUD, s. 294], Spang [DUD, s. 574].

\section{FUNKCJA EKSPRESYWNA}

Badacze zajmujący się cyklem ukraińskim wielokrotnie podkreślali sugestywność stylu tej prozy oraz jej niezwykłą intensywność emocjonalna. W odniesieniu do nazw własnych, szczególnie antroponimów, których funkcja ekspresywna polega na takim ich użyciu w tekście literackim, aby nadawały wyrazistości i wywoływały przewidywaną reakcję odbiorcy [Kosyl, 1992, s. 129], Odojewski ogranicza się do najprostszych zabiegów onomastycznych, co widoczne jest w imiennictwie.

Imiona określające Polaków występują prawie zawsze w pełnych, metrykalnych formach, np. żeńskie: Dominika, Irena, Katarzyna, Konstancja, Matgorzata, męskie: Pawel, Piotr, Teodor, Stefan. Podobnie jest w przypadku większości postaci ukraińskich, które noszą pełne imiona ukraińskie, np.: Semen, Iwan, Nikodem, Wasyl. Nieliczne formy hipokorystyczne pojawiające się w imionach wschodniosłowiańskich i utworzone sufiksem -ko, np.: Filipko, Nikitko, Wasylko, są formami potocznymi. 
Uwagę zwraca formacja patronimiczna Pawluk, utworzona od imienia Pawet sufiksem -uk. Używa jej mówiący polsko-ukraińską gwarą ranny partyzant Kuprian Szyła, prosząc Pawła Woynowicza: „Ne załyszajte mene, chłopci, na Chrysta, Pawluk; [...] Zakopajte, Pawluk. Przecie oni nawet ciała nie uszanują. Chot'by zakopaty w zemlu. Myż jednego klejnotu, Pawluk, pomnij” [ZWZ, s. 455].

Źródło ekspresywności warstwy antroponimicznej analizowanych utworów tkwi więc $\mathrm{w}$ wyraźnym przeciwstawieniu dwóch systemów imienniczych, polskiego i wschodniosłowiańskiego, wywodzących się jednak ze wspólnego trzonu imion chrześcijańskich. Niewielkie nasycenie cyklu podolskiego formami deminutywnymi i hipokorystycznymi, których wartość emocjonalna szczególnie predestynuje do pełnienia funkcji ekspresywnej, wynika po części z tematyki utworów, ale także z zastosowanej przez autora techniki narracji w postaci wspomnianego już strumienia świadomości.

\section{FUNKCJA SEMANTYCZNA}

Nazwa własna pełni w dziele literackim funkcję semantyczną, jeśli:

[...] znaczenie wyrazu motywującego nazwę wiąże się w jakiś sposób z charakterystyką obiektu literackiego oznaczonego przez tę nazwę [Kosyl, 1992, s. 44].

Niektóre nazwy osobowe w utworach Odojewskiego są motywowane jakimiś cechami oznaczanych przez nie denotatów i pełnią tym samym funkcję semantyczną.

Taką nazwą jest omówione wyżej nazwisko Czerestwienski, którego budowa i znaczenie tworzącego go leksemu czerez 'przez' określa rodzinę, która w wyniku historycznych zmian zmuszona była przejść przez granicę państwową - z Rosji do Polski.

Funkcję semantyczną pełni także imię Katarzyna, które nosi główna bohaterka - wdowa po Aleksym, kochanka Pawła Woynowicza i Piotra Czerestwienskiego, oddana przez Semena Gawryluka do domu publicznego przeznaczonego dla żołnierzy niemieckich. Pierwotne znaczenie imienia, które łączy się z gr. ap. catharos 'czysty, niepokalany, bez skazy, prawy' [KNI, s. 172], odnosi się do sytuacji życiowej bohaterki na zasadzie kontrastu. Motywacja semantyczna, polegająca na sprzeczności między dosłownym znaczeniem leksemu motywującego imię a losami postaci to imię noszącej, jest ukrytą aluzją do niezawinionych losów kobiet zamieszkujących Podole w czasie wojny i bratobójczych walk [Krzyżanowski, 1999, s. 327-328]. 


\section{FUNKCJA INTERTEKSTUALNA}

O intertekstualności onimicznej można mówić wówczas, gdy do utworu literackiego wprowadzone zostały onimy prymarnie należące do onomastykonów innych dzieł [Graf, 2015, s. 187]. Analizując funkcję intertekstualną nazwy, należy brać pod uwagę nie tylko nazwę, ale także leksykalny i tekstowy kontekst, w jakim została ona umieszczona. Trylogia Odojewskiego wykazuje związki z romantycznym mitem ukraińskim, podkreślającym fatalizm losów dziejowych tych ziem oraz świadomość napięć i konfliktów wynikających z współbytowania różnych narodów, kultur i religii. Intertekstualne odwołania do romantycznej literatury widoczne są na płaszczyźnie onimicznej. Czytelną aluzją do dramatu mistycznego Juliusza Słowackiego Sen srebrny Salomei jest imię Semen, które w bezpośredni sposób nawiązuje do postaci noszącej imię Semenko z utworu Słowackiego - ukraińskiego kozaka kierującego się w swoim postępowaniu w czasach koliszczyzny (tak jak Semen w utworach Odojewskiego) mściwością i pragnieniem zemsty. Funkcja intertekstualna imion bohaterów - Semen i Semenko - łączy się tutaj z określonymi wartościami konotacyjnymi, to znaczy z „ukraińskością” ich nosicieli, ale także z powtarzającymi się na tych ziemiach krwawymi napięciami i konfliktami narodowymi.

Innym przykładem nazewniczych nawiązań intertekstualnych jest nazwisko Laudański, którym określany jest dowódca partyzantki polskiej. Według relacji jednego z bohaterów był on „drobnym rolnikiem” [ZWZ, s. 281]. Być może nazwisko to i postać pułkownika Laudańskiego nawiązuje do szlachty laudańskiej - zubożałych rodzin szlacheckich zamieszkujących tereny nad Laudą na Kowieńszczyźnie. Owa zubożała szlachta laudańska występuje w Potopie Henryka Sienkiewicza i nazwisko Laudański może być intertekstualnym nawiązaniem do niego.

\section{FUNKCJA MITOTWÓRCZA}

Przedstawione wyżej osobowe nazwy własne w cyklu kresowym Odojewskiego pełnią jeszcze jedną ważną funkcję - mitotwórczą ${ }^{14}$. Zdaniem Ewy Sławkowej funkcja mitotwórcza onimów w literaturze przysługuje tej prozie współczesnej, która:

[...] stworzyła specyficzny typ epiki określanej mianem literatury „utraconych ojczyzn”, ewokującej ziemie zmiecione z mapy Europy przez pierwszą czy drugą wojnę światową lub te, które za ich sprawą zmieniły całkowicie swoją przynależność państwową, odnajdując się [...] w obrębie innych krajów Europy Wschodniej [Sławkowa, 2012, s. 187].

${ }^{14}$ Mitotwórczy charakter prozy Odojewskiego podkreślają badacze jego twórczości - zob. literatura podana $\mathrm{w}$ przypisie 2 . 
Do literatury tego typu niewątpliwie należy cykl podolski Włodzimierza Odojewskiego. Funkcja mitotwórcza nazw własnych związana jest z ich uczestnictwem w tworzeniu pewnego obrazu ,utraconych bezpowrotnie krain”, będących obszarami językowo-kulturowych pograniczy [Sławkowa, 2012, s. 188]. W analizowanych utworach antroponimy określają swoich nosicieli jako należących do różnych grup społeczności kresowej - polskiej, ukraińskiej, rosyjskiej, żydowskiej, niemieckiej. Funkcja identyfikacyjna i socjologiczna onimów łączy się z funkcją mitotwórczą. Za pomocą nazw osobowych pisarz kreuje obraz kresów podolskich jako świata, któremu zróżnicowanie etniczne nadaje charakterystyczne piętno. Nazewnictwo osobowe uczestniczy w odtworzeniu obrazów bezpowrotnie utraconych ziem, pełnych zadawnionych napięć i konfliktów etnicznych. Odojewski w cyklu podolskim odtwarza mit Ukrainy jako pogranicza polsko-ukraińsko-rosyjsko-żydowskiego, z jego językowo-kulturową różnorodnością wpisaną w katastroficzną wizję rozpadu dotychczasowego świata Kresów Wschodnich ${ }^{15}$.

\section{ZAKOŃCZENIE}

Przedstawiony w cyklu podolskim paradygmat antroponimiczny, w którego skład wchodzą przede wszystkim imiona i nazwiska pochodzenia polskiego, ukraińskiego, a także rosyjskiego, żydowskiego i niemieckiego - autentyczne leksykalnie lub nieautentyczne leksykalnie, ale realistyczne - pełnią różnorodne funkcje: lokalizacji w czasie i przestrzeni, informacyjna, identyfikacyjno-dyferencjacyjna, socjologiczna, semantyczną, ekspresywną, intertekstualną. Wszystkie te funkcje strefy proprialnej łączą się z funkcją mitotwórczą, polegającą na odtworzeniu obrazu niejednolitych pod względem etniczno-językowym i kulturowym

${ }^{15}$ Ten katastrofizm ujmuje jeden z bohaterów trylogii, Teodor Czerestwienski, który mówi do Pawła Woynowicza: „Czasem wydaje mi się, że rozumiem wszystko, czasem, że nic. Oczywiście, tobie zależy na tej ziemi w sensie jak najbardziej dosłownym, bo jej kawałek jest twoją rodzinną własnością od kilku wieków, i także w przenośnym, bo uważasz, że to twój kraj. Ukraińcy mówią, że to wyłącznie ich kraj i macie iść stąd precz. Ale na dobrą sprawę ty i tobie podobni nie jesteście nikim innym, jak Ukraińcami. Albo Rusinami. W końcu to jedno i to samo. Nie o nazwę przecież chodzi. W którymś tam pokoleniu zmieniliście wyznanie, najczęściej zaś język, czasem i to, i tamto równocześnie, nie przestaliście jednak być Rusinami. Jesteście więc wy, mówiący po polsku - dawna szlachta czy chłopi, wszystko jedno - autentycznymi synami tej ziemi. Zatem o co nienawiść? O język? Też nie. Ten Tomecki, słyszałeś, mówi przecież po polsku, a właśnie on należy do bandy Gawryluka. Natomiast w waszej partyzantce są również ludzie mówiący po ukraińsku. Nie język zatem ani narodowość rozgranicza. Myślałem dawniej, że nędza i bogactwo. [...] Może przyczyna tego, co tu się dzieje, tkwi gdzie indziej? Może jak mozaika składa się z wielu elementów, których nie umiem poskładać?" [ZWZ, s. 280-281]. 
Kresów Wschodnich. Autentyczność i realistyczność antroponimów sprawiają, że nazewnictwo prozy Odojewskiego zaliczyć należy do realistycznego nurtu stylistycznego [Kosyl, 2005, s. 365].

\section{ROZWIĄZANIA SKRÓTÓW}

Skróty konwencjonalne

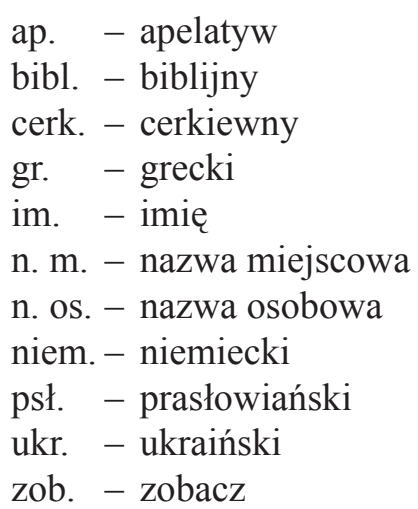

\section{Źródła}

WO - OdoJEwski Włodzimierz, 1990, Wyspa ocalenia, Zakłady Wydawnicze „Wersu”, Białystok.

ZŚ - OdoJewski Włodzimierz, 2005, Zmierzch świata, Wydawnictwo Książkowe Twój Styl, Warszawa.

ZWZ - ODoJewski Włodzimierz, 2008, Zasypie wszystko, zawieje..., Świat Książki, Warszawa.

\section{Słowniki}

DUD - Kohlheim Volker Rosa, 2008, Lexikon der Familiennamen, Dudenverlag, Mannheim-Leipzig-Wien-Zürich.

IŻ - KośKa Lidia, 2002, Imiona przez Żydów polskich używane, Wydawnictwo Austeria, Kraków.

KNI - BubaK Józef, 1993, Księga naszych imion, Zakład Narodowy im. Ossolińskich, Wrocław-Warszawa-Kraków.

NP I - Rymut Kazimierz, 1999, Nazwiska Polaków. Słownik historyczno-etymologiczny, t. 1, Wydawnictwo Instytutu Języka Polskiego Polskiej Akademii Nauk, Kraków. 
NP II - Rymut Kazimierz, 2001, Nazwiska Polaków. Stownik historyczno-etymologiczny, t. 2, Wydawnictwo Naukowe DWN, Kraków.

SEM - CieśLIKowa Aleksandra, Malec Maria, Rymut Kazimierz, red., 1995-2002, Stownik etymologiczno-motywacyjny staropolskich nazw osobowych, cz. 1-7, Pracownia Antroponimiczna Instytutu Języka Polskiego Polskiej Akademii Nauk, Kraków.

SEŻ - Abramowicz Zofia, 2003, Stownik etymologiczny nazwisk Żydów biatostockich, Wydawnictwo Uniwersytetu w Białymstoku, Białystok.

SIP - Charkiewicz Jarosław, red., 2011, Stownik imion prawosławnych w brzmieniu polskim i staro-cerkiewno-stowiańskim, Warszawska Metropolia Prawosławna, Warszawa.

\section{BIBLIOGRAFIA}

BARĆ Stanisław, wybór i oprac., 1999, Odojewski i krytycy. Antologia tekstów, Wydawnictwo Uniwersytetu Marii Curie-Skłodowskiej, Lublin.

BIEŃKowski Zbigniew, 1999, Odojewszczyzna, w: S. Barć, wybór i oprac., Odojewski i krytycy. Antologia tekstów, Wydawnictwo Uniwersytetu Marii Curie-Skłodowskiej, Lublin, s. 238-241.

CIEŚLIKOwa Aleksandra, 2001, Nazwa w tekście a tekst w nazwie, w: A. Pajdzińska, R. Terlecki, red., Semantyka tekstu artystycznego, Wydawnictwo Uniwersytetu Marii Curie-Skłodowskiej, Lublin, s. 99-108.

CZERwIŃski Grzegorz, 2011, Po rozpadzie świata: o przestrzeni artystycznej w prozie Włodzimierza Odojewskiego, Wydawnictwo słowo/oraz terytoria, Gdańsk.

Graf Magdalena, 2015, Literackie nie-nazywanie. Onomastykon polskiej prozy współczesnej, Wydawnictwo Naukowe Uniwersytetu Adama Mickiewicza, Poznań.

Iwasiów Inga, 1994, Kresy w twórczości Włodzimierza Odojewskiego. Próba feministyczna, Wydawnictwo Jota, Szczecin.

KARPLUK Maria, 2009, Zapamiętane nazwiska mieszkańców Brodów (1935-1943), w: M. Skarżyńki, M. Szpiczakowska, red., W kręgu języka. Materiały konferencji ,Stowotwórstwo-stownictwo-polszczyzna kresowa” poświęconej pamięci Profesor Zofii Kurzowej Kraków 16-17 maja 2008, Księgarnia Akademicka, Kraków.

Kosyl Czesław, 1992, Nazwy własne w prozie Jarosława Iwaszkiewicza, Wydawnictwo Uniwersytetu Marii Curie-Skłodowskiej, Lublin. 
Kosyl Czesław, 2005, Nazwy własne w literaturze pięknej, w: E. Rzetelska-Feleszko, red., Polskie nazwy własne. Encyklopedia, wyd. II, Wydawnictwo Instytutu Języka Polskiego Polskiej Akademii Nauk, Kraków, s. 263-287.

KRZYŻANOwSKI Jerzy Roman, 1999, Kreowany świat Kresów Włodzimierza Odojewskiego, w: S. Barć, wybór i oprac., Odojewski i krytycy. Antologia tekstów, Wydawnictwo Uniwersytetu Marii Curie-Skłodowskiej, Lublin, s. 318-332. LesZCZYC Zbigniew, 1990, Herby rodów polskich, Orbis Books, London.

Rembowska-PŁuciennik Magdalena, 2004, Poetyka i antropologia. Cykl podolski Włodzimierza Odojewskiego, Wydawnictwo Universitas, Kraków.

Sarnowska-Giefing Irena, Graf Magdalena, GrZelak-Piaskowska Joanna, red., 2013, Bibliografia polskiej onomastyki literackiej za lata 2001-2013 (z uzupetnieniami za lata wcześniejsze), Wydawnictwo Rys, Poznań.

SarnowsKa-Giefing Irena, Korzeniowska-Gosieniecka Magdalena, red., 2001, Bibliografia polskiej onomastyki literackiej do roku 2000, Wydawnictwo WiS, Poznań.

SŁawKowa Ewa, 2012, Tekst literacki w kręgu językoznawstwa, Wydawnictwo Gnome, Katowice.

Stabro Stanisław, 2002, Literatura polska 1944-2000 w zarysie, Wydawnictwo Uniwersytetu Jagiellońskiego, Kraków.

Szczeprowska Ewa, 2002, Cykl podolski Włodzimierza Odojewskiego. Postacie.

Krajobrazy. Obszary pamięci, Wydawnictwo Instytutu Badań Literackich Polskiej Akademii Nauk, Warszawa.

Tichoniuk Bazyli, 2000, Imiona i ich formy na pograniczu polsko-białoruskim od XVI wieku do roku 1839, Wydawnictwo Wyższej Szkoły Pedagogicznej im. Tadeusza Kotarbińskiego, Zielona Góra.

Wolnicz-PawŁowska Ewa, Szulowska Wanda, 1998, Antroponimia polska na Kresach poludniowo-wschodnich $X V-X I X$ wiek, Towarzystwo Naukowe Warszawskie Instytut Slawistyki Polskiej Akademii Nauk, Warszawa.

\section{Zofia Kubiszyn-Mędrala}

\section{ANTROPONIMY W UTWORACH KRESOWYCH WŁODZIMIERZA ODOJEWSKIEGO I ICH FUNKCJE ARTYSTYCZNE}

\section{Streszczenie}

W artykule omówione zostały antroponimy (imiona i nazwiska) występujące w trzech utworach tworzących tzw. cykl kresowy Włodzimierza Odojewskiego. Autorka przedstawia ich genezę i etymologię oraz pełnione przez nie funkcje artystyczne. Nazwiska osób realnie istniejące w świecie 
pozaliterackim w trylogii kresowej pełnią funkcję lokalizacji w czasie i/lub przestrzeni. W nazywaniu postaci fikcyjnych autor sięga po autentyczne imiona i nazwiska występujące na terenach będących miejscem akcji utworów. Nazwy te charakteryzują postaci ze względu na ich pochodzenie narodowe, społeczne i terytorialne (funkcja socjologiczna). Nieautentyczne nazwisko Czerestwienski skupia funkcję socjologiczną, treściową i semantyczną. Literacki antroponomastykon trylogii pełni ponadto funkcję ekspresywną, intertekstualną i mitotwórczą.

\section{ANTHROPONYMS IN THE KRESY WORKS BY WŁODZIMIERZ ODOJEWSKI AND THEIR ARTISTIC FUNCTION}

Summary

In the article the author considers the anthroponyms occurring in three works constituting the so-called "Kresy cycle" by Włodzimierz Odojewski. The author presents the origin and etymology of examined names as well as their artistic functions. The surnames of people existing in the non-literary world in the Kresy trilogy have the function of locating in time and/or in space. When naming literary figures, Odojewski refers to authentic names and surnames that occur in the region where the action of his literary works takes place. The names characterize literary figures by their national, social and territorial origin (they have a sociological function). The non-authentic surname Czerestwienski condenses the sociological, content and symbolic functions. Furthermore, the literary anthroponyms in the trilogy have an expressive, intertextual and mythogenic function. 